\title{
Advancements in adeno-associated viral gene therapy approaches: exploring a new horizon Caroline J. Aalbers ${ }^{1,2}$, Paul P. Tak ${ }^{1,2 *}$ and Margriet J. Vervoordeldonk ${ }^{1,2}$
}

Addresses: ${ }^{1}$ Division of Clinical Immunology and Rheumatology, Academic Medical Center / University of Amsterdam, Amsterdam, The Netherlands; ${ }^{2}$ Arthrogen BV, Amsterdam, The Netherlands

* Corresponding author: Paul P. Tak (p.p.tak@amc.uva.nl)

FI000 Medicine Reports 201I, 3:17 (doi:10.3410/M3-17)

This is an open-access article distributed under the terms of the Creative Commons Attribution-Non Commercial License (http://creativecommons.org/licenses/by-nc/3.0/legalcode), which permits unrestricted use, distribution, and reproduction in any medium, provided the original work is properly cited. You may not use this work for commercial purposes.

The electronic version of this article is the complete one and can be found at: http://f $1000 . c o m / r e p o r t s / m / 3 / 17$

\begin{abstract}
Gene therapy is a promising new therapeutic strategy that has been explored in a wide variety of diseases, ranging from cancer to hemophilia, and ocular disorders to autoimmune diseases, among others. Proof of concept of gene transfer approaches has been shown in over 100 studies of animal models of disease, although only a few are under development for clinical application. The US Food and Drug Administration and the European Medicines Agency have not approved any viral human gene therapy products for sale so far, but the amount of gene-related research and development occurring in the United States and Europe continues to grow at a fast rate. This review summarizes the current status of developments in the field of viral gene therapy using adeno-associated virus as a vector, with a special focus on arthritis. For rheumatoid arthritis, and to a lesser extent for other immune-related inflammatory disorders, several cell and gene transfer approaches have been investigated at the preclinical level and a few have been implemented in clinical trials. Finally, both the potential and the hurdles that are faced during development of a viral gene therapy through to its clinical application are discussed.
\end{abstract}

\section{Current state and perceived benefits of adeno-associated virus gene therapy}

Gene therapy offers the potential to "cure" inherited diseases caused by a single error in a single gene in the human DNA, responsible for a heavy loss of life and quality of life. Diseases caused by a single error in a single gene represent approximately $1 \%$ of births worldwide (examples include hemophilia and cystic fibrosis). In principle, gene therapy in these diseases could introduce (using a vector) a replacement for the defective gene into the patient's cells to restore function. It could also be used to treat other diseases that arise from a more complex mix of genetic and/or environmental factors (such as rheumatoid arthritis, Parkinson's disease, and cancer) by introducing a gene encoding a therapeutic agent into the affected cells or other target cells. Today, we can envisage a time when we will be able to use gene therapies in the clinic to treat a spectrum of currently incurable or virtually untreatable diseases. In practice, however, introducing the desired gene into the host cells and getting them to express it in a useful and safe manner for an extended period of time still poses problems. Recent advances have now brought us closer to this goal, and here we outline some of these advances, particularly in systems for treating nonlethal diseases.

The most efficient types of vector to deliver DNA into a cell are viruses that have been genetically modified to carry therapeutic genes. Most of the viral genes are removed from these viruses to prevent replication of the virus and to reduce its immunogenicity. Unquestionably, viruses that infect eukaryotic cells have been the vectors of choice for gene delivery to mammalian cells. Adenoassociated virus (AAV) vectors have been identified as the current most promising gene delivery candidate for serious nonlethal diseases that need long-term treatment. 
AAV is a small, nonenveloped single-stranded DNA virus that infects humans, and is from the Parvoviridae family. AAV has a high safety profile (because it does not induce a large inflammatory response), a lack of toxicity and, due to the existence of different serotypes of the virus, can transduce (transfer into a cell) a wide variety of tissues and cells in vivo; moreover, long-term expression can be achieved without integration [1]. In over 60 trials, AAV-based therapeutic strategies have been tested in humans, some of which have shown very promising results at immunoprivileged sites. Several clinical trials have shown success in terms of initial safety and proof of concept. To date, one AAV-based therapeutic vector has been submitted to the European Medicines Agency (EMA) for evaluation. However, these clinical trials have also identified problems associated with vector administration in humans that were not seen during the preclinical studies in rodents and were not even seen in nonhuman primates. This includes the presence of pre-existing neutralizing antibodies to the AAV vector, loss of transgene expression over time, and (too) low expression of the transgene. In addition, certain studies, like a Phase IIB trial in patients with cystic fibrosis, showed that the AAV vector was well tolerated and safe, but no significant improvement in lung function could be observed, probably due to low transduction efficiency of the AAV vector. Consequently, research to overcome these barriers to the development of safe and effective gene therapy in various disease areas is ongoing.

\section{Clinical trials using AAV as vector for different diseases}

Clinical studies for the treatment of alpha1-antitrypsin deficiency, Alzheimer's disease, arthritis, Batten's disease, Canavan's disease, cystic fibrosis, hemophilia B, HIV infection, Leber's congenital amaurosis, lipoprotein lipase (LPL) deficiency, Parkinson's disease, muscular dystrophy, and malignant melanoma have been initiated (see Gene Therapy Clinical Trials Worldwide, provided by the Journal of Gene Medicine [2]). A few of these trials demonstrating the recent advances and hurdles in the field of AAV clinical gene therapy will be highlighted below.

\section{Leber's congenital amaurosis}

The first clear demonstration of long-term efficacy following administration of a transgene with an AAV vector in humans was demonstrated in two independent Phase I AAV clinical trials in ophthalmological disease. The eye is an easily accessible, highly compartmentalized and immune-privileged organ offering unique advantages for local gene therapy. The objective was to treat blindness in patients affected by Leber's congenital amaurosis, an autosomal recessive disease leading to blindness. Both trials used the AAV2 serotype vector. One was performed in London, UK, and the other in Philadelphia, USA. The main differences between the trials were the use of a constitutive promoter to drive transgene expression in the US trial [3], compared with the use of elements of the endogenous (host) RPE65 (retinal pigment epithelium-specific $65 \mathrm{kDa}$ protein) promoter in the UK trial [4]. Moreover, the patients treated in the UK were all adolescent; no children with less progressive disease were treated. In both studies, only subjects in whom the disease was caused by a deficiency in human RPE65, responsible for blindness in approximately $10 \%$ of the patients with Leber's congenital amaurosis, were included.

The first trial was performed in the United States; a single eye was treated in each of 12 pediatric and adult subjects (8-44 years) by a subretinal injection of an AAV2 vector containing the RPE65 gene in one of three doses $\left(1.5 \times 10^{10}\right.$ vector genomes $[\mathrm{vg}], 4.8 \times 10^{10} \mathrm{vg}$, and $1.5 \times 10^{11} \mathrm{vg}$ ) This trial showed an excellent safety profile and objective evidence of long-term efficacy [5]. AAV2-hRPE65v2 was well tolerated and all patients showed sustained improvement in subjective and objective measurements of vision. The greatest improvement was noted in children. No neutralizing antibody levels were detectable after the first injection. Since patients who had one eye treated experienced such an improvement in vision, they requested treatment of their second eye. Results of injection of the second eye in patients previously receiving the gene therapeutic vector are awaited and are important, as they will show whether redosing with the same AAV serotype in an immune-privileged site is feasible without inducing an immune response against the vector. In the second trial, performed in the UK, three patients in the age range of 17 to 23 years were treated. All patients received doses of $1 \times 10^{11}$ vector particles. Visual function improved in only one patient; the other two probably had more advanced retinal disease at baseline, which may explain why they did not exhibit clinical improvement. Whether further retinal degeneration is delayed in any of the patients will become apparent only after several years. The comparison between the effect of a constitutive AAV promoter versus a host tissue-specific promoter in terms of safety and efficacy will be of particular interest. Even though only a small percentage of patients will directly benefit from this particular treatment, the general technique of AAV-mediated transfer of a transgene into retinal cells has been shown to work well, and will likely be used in other forms of retinal blinding disorder in the near future. Overall, different treatment strategies based on AAV-mediated gene therapy approaches are in the pipeline for retinal blinding disorders and may soon advance to the clinic [6]. 


\section{Hemophilia B}

Hemophilia $\mathrm{B}$ is an attractive target disease for gene therapy, as stable expression of coagulation factor IX may correct the bleeding diathesis. Initial clinical trials for hemophilia, using different vectors, showed that gene therapy was safe but did not demonstrate any therapeutic effect. In 1999, a Phase I/II clinical trial was initiated to test the safety and efficacy of intramuscularly delivered AAV vectors encoding a cytomegalovirus-driven factor IX transgene [7]. No toxicity was observed over 7 years of follow-up after vector administration. Muscle biopsies taken 2 months, 10 months, and $>3$ years after vector administration revealed the persistence of vector genomes as well as local expression of the factor IX protein. However, these levels of factor IX were not therapeutically effective. In this study, the barrier to the use of this approach as a treatment was the number of muscle injections required to reach a therapeutic effect in an adult hemophilia B patient.

Next, a second clinical trial testing the safety and efficacy of an AAV vector was initiated [8]. In this trial, a liverspecific promoter was used to drive expression of the factor IX transgene. The vector was infused into the hepatic artery of hemophilia B subjects at three different doses. Only one patient treated with the highest dose $\left(2 \times 10^{12} \mathrm{vg} / \mathrm{kg}\right)$ showed expression of the transgene 2 weeks after vector infusion; however, thereafter levels slowly declined to reach baseline after a further 8 weeks. This decrease was accompanied by an increase in liver transaminase levels, which indicates transaminitis (reflecting liver cell damage). It was demonstrated that the loss of transgene expression was caused by a T-cellmediated response to the vector capsid resulting in elimination of the transduced hepatocytes [9]. Importantly, the T-cells' activation and transaminase response appeared to be vector-dose dependent and was not seen in patients treated with a lower vector dose. This phenomenon had not been observed in any animal model after AAV transduction, but unlike most laboratory animals, humans are frequently exposed to wildtype $\mathrm{AAV}$ viruses in the context of pathogens from very early childhood. These exposures, because they occur in the context of helper viruses such as adenovirus, which evoke a strong immune response, may also evoke an immune response to $\mathrm{AAV}$ vector proteins that could be reactivated by the AAV vector.

There are possible ways to counter this immunogenicity: conceivably, transient immunosuppression may potentially overcome T-cell-mediated immune responses; alternatively, vectors could be developed that result in higher factor IX expression levels at much lower vector doses. Indeed, the latter strategy has been investigated in nonhuman primates [10]. A self-complementary AAV (scAAV) vector was generated, containing doublestranded DNA instead of single-stranded DNA and therefore not requiring double-strand synthesis after transduction into the cell. This resulted in a higher transgene expression with lower doses of vector. In addition, the transgene was packaged in an AAV serotype 8 capsid, which has an advantage over the AAV2 vector regarding the reduced presence of pre-existing antibodies to the vector in humans, and results in reduced uptake by antigen-presenting cells compared to AAV2 (due to the tropism of AAV8). Based on the preclinical data, a GMP (Good Manufacturing Practice) batch was produced [11] and a Phase I/II clinical trial has recently been initiated in patients with hemophilia B. In another trial in Philadelphia, the former approach of concomitant immune suppression is currently under investigation.

\section{Lipoprotein lipase deficiency}

LPL deficiency is an autosomal recessive disease associated with severe hypertriglyceridemia, severe chylomicronemia, and low levels of high-density lipoprotein, which can lead to acute pancreatitis. Currently, no drug therapy is available but gene therapy with LPL could be a good option for these patients. An AAV1 vector, expressing the human LPL variant $\mathrm{LPL}^{\mathrm{S} 447 \mathrm{X}}$, was generated and tested in a Phase I/II, open-label (i.e., not blinded) doseescalation clinical trial and followed by a Phase II/III study [12]. AAV1.LPL ${ }^{\text {S447X }}$ (AMT-011, alipogene tiparvovec, Glybera) was administrated by a single series of intramuscular injections in multiple sites of the limbs (range from 30-70 injections, depending upon body weight). In the first study, the gene therapy vector was well tolerated at a dose of $3 \times 10^{11} \mathrm{vg} / \mathrm{kg}$. No data about expression levels are available but, in two of the four subjects treated with the highest dose, a $>40 \%$ reduction in triglyceride levels was observed, which could obviously not be compared to controls. T cell immune responses against AAV1 capsid were detected in half of the subjects in the first month after administration of the drug [13]. In the second study (performed in Quebec, Canada), 14 patients were included. This study was a dose-escalation study with two patients receiving a dose of $3 \times 10^{11} \mathrm{vg} / \mathrm{kg}$, four patients receiving the same dose as the first group but in combination with immunosuppressive medication to avoid the T-cell responses, and eight in the highest dose group $\left(1 \times 10^{12} \mathrm{vg} / \mathrm{kg}\right)$ in combination with immunosuppressants. Immunosuppressive treatment consisted of cyclosporine $(3 \mathrm{mg} / \mathrm{kg})$ and mycophenolate mofetil ( $2 \mathrm{~g} /$ day) from day 3 until 12 weeks after study drug administration. In a third study, the protocol was modified to include an additional bolus injection of the anti-inflammatory drug methylprednisolon prior to the vector. As five patients with a previous 
history of acute pancreatitis were included in the third study, it will be interesting to see the incidence of pancreatitis in LPL following AAV1.LPL ${ }^{\text {S447X }}$ gene therapy over the coming years. In summary, AAV1.LPL ${ }^{\mathrm{S} 447 \mathrm{X}}$ was tolerated well, without dose-limiting toxicity; also, in long-term follow-up, this therapy has produced an excellent safety profile so far [14]. During the active study phase, a decrease in triglyceride levels was noted in virtually all patients. Muscle biopsies taken half a year later in the second group from both injected and noninjected muscle clearly indicated persistent expression and biologic activity. Alipogene tiparvovec is now under review at the EMA as a new therapeutic agent for LPL deficiency. If the submission is approved by the EMA in the next year, then alipogene tiparvovec might be the first (AAV) gene therapy compound on the market in Europe.

\section{Rheumatoid arthritis}

Rheumatoid arthritis is a progressive destructive disorder primarily targeting the joints. Advances in the understanding of the pathophysiology of rheumatoid arthritis have allowed important and innovative approaches to its treatment. During the last decade, development of therapies targeting tumor necrosis factor (TNF) and other new drugs, together with an improved timing and dosing of conventional therapy, has largely improved the outcome of established arthritis in many patients, but cannot induce a complete remission in all. Most of the patients still have some level of synovial inflammation in one or more joints. Another major problem of current systemic treatment is the need for ongoing therapy.

Gene therapy could theoretically offer long-term treatment, resulting in sustained remission without the need for frequent repeated treatments. Although various proof-of-concept strategies have been demonstrated in preclinical models, those aimed at direct in vivo gene delivery to the synovial tissue in the joints are closest to clinical application.

\section{Gene therapy studies using AAV in animal models of rheumatoid arthritis}

Since it has been shown that TNF plays a key role in the initiation and perpetuation of synovial inflammation, and biologicals targeting TNF are successful in treating rheumatoid arthritis in both animal models and patients, several gene therapeutic approaches aimed at blocking TNF activity have been tested in the past few years. In one of the studies using streptococcal cell wall-induced arthritis in rats [15], intra-articular administration of a recombinant AAV2 vector containing CDNA encoding a rat p75 TNF receptor-2 (TNFR2):Fc fusion gene suppressed arthritis. This study formed the basis for a clinical trial in which a recombinant AAV2 vector expressing the human TNFR2:Fc protein, a protein identical to the antiTNF drug etanercept, was tested in patients with inflammatory disease (see Clinical trials in rheumatoid arthritis section, below).

Most of the preclinical and clinical data for rheumatoid arthritis have been generated using AAV serotype 2 as a vector. However, in 2005, two independent studies compared serotypes 1 to 5 , and showed that recombinant AAV serotype 5 was the most efficient recombinant AAV vector for transducing synovial tissue in vivo, followed by recombinant AAV2 $[16,17]$. Subsequently, the transducing efficiency of recombinant AAVs was demonstrated in inflamed joints of horses [18]. In addition to its superior transduction efficiency, AAV5 has the important advantage that neutralizing antibodies against AAV5 are rare in the human population compared with AAV2 [19]. We have demonstrated that this also holds true in rheumatoid arthritis patients (unpublished results). Both preclinical and clinical studies showed that antibodies against the AAV capsid may block transduction at very low titers when the vector is introduced into the bloodstream [20], even when it is close to the target tissue, whereas gene transfer in immune-privileged body compartments, such as the eye and the brain, seems to be less susceptible to neutralization. In another step forward, recombinant AAV5 gene constructs expressing a TNF-blocking agent, a chimeric human TNF soluble receptor-1 linked to a mouse immunoglobulin heavy chain Fc portion (TNFR1:Fc), reduced arthritis score, paw swelling, and joint destruction in two animal models of arthritis [21,22].

Another approach, which has been investigated by several groups, is the overexpression of anti-inflammatory cytokines locally in the joint. Our own group explored inducing overexpression of interferon-beta (IFN $\beta$ ) in inflamed joints. After successful treatment of arthritis with IFN $\beta$ protein in animal models, we showed that intra-articular IFN $\beta$ gene therapy using recombinant AAV5-expressing rat IFN $\beta$ resulted in reduced paw swelling and synovial inflammation in rat adjuvant arthritis [23]. In addition, IFN $\beta$ treatment protected against bone and cartilage destruction. Similarly, toxicity and biodistribution studies have been initiated, evaluating the effects of a clinical recombinant AAV5 vector expressing human IFN $\beta$ (ART-I02) in collagen-induced arthritis in rhesus monkeys. Preliminary results indicated that local treatment with high doses of ART-I02 is not toxic and is well tolerated in the animals, but also revealed the production of neutralizing antibodies to the vector after local injection in the joint. Although this does not interfere with the transduction of cells in vivo after the first administration of the vector, it can 
potentially have an effect on repeated administration of the vector if a second injection is needed. The next step will be the performance of pharmacology and toxicology studies under GLP (Good Laboratory Practice) conditions before conducting a Phase I clinical trial in rheumatoid arthritis patients.

\section{Clinical trials in rheumatoid arthritis}

To date, only a few clinical gene therapy trials have been performed in rheumatologic diseases, with four trials targeting proinflammatory cytokines for the treatment of rheumatoid arthritis. The first gene therapy trial in rheumatoid arthritis patients investigated safety and feasibility of ex vivo gene therapy [24]. Autologous fibroblast-like synoviocytes were transduced with a retroviral vector expressing interleukin-1 receptor antagonist (IL-1RA). After 1 week, injected joints were removed and examined for evidence of successful gene transfer. In joints treated with transduced cells, mRNA transgene expression was shown, as well as clusters of cells expressing high levels of IL-1RA. No adverse events were recorded. Despite these promising results, this ex vivo gene therapy approach was not further developed for clinical application because of the expense and time involved.

More recently, Targeted Genetics Corporation performed two clinical trials in rheumatoid arthritis patients using an in vivo gene therapy approach with recombinant AAV2 $[25,26]$. The Phase I study investigated the safety of an intra-articular injection of a recombinant AAV2 vector coding for a TNF receptor IgG1 fusion gene (tgAAC94). Doses up to $1 \times 10^{11}$ particles per milliliter of joint volume were well tolerated. Subsequently, in a Phase I/II study, the clinical response to administration of tgAAC94 was investigated in 127 patients with inflammatory arthritis (including rheumatoid and psoriatic arthritis, and those with other arthritides). Patients received a single intra-articular injection of tgAAC94 (at three different dosages: $1 \times 10^{11}, 1 \times 10^{12}$, or $1 \times 10^{13}$ particles per milliliter of joint volume) or placebo. This treatment was followed by an open-label injection after 12-30 weeks. No change in arthritis score was observed upon physical examination, but patientreported outcomes did show a nonsignificant trend towards a response. Common adverse reactions were injection site reactions, but otherwise the treatment was well tolerated. The study encountered one serious adverse event: one patient, who was on concurrent systemic antiTNF antibody treatment, developed fatal disseminated histoplasmosis, a fungal infection, which was ultimately considered unrelated to the study agent [27].

These trials provided encouraging data on safety and feasibility for further development of gene therapy for rheumatoid arthritis. Future clinical trials will need to address whether long-term expression of a therapeutic gene and therapeutic efficacy can be obtained using other recombinant AAV vectors. It will also be important to exclude patients with significant pre-existing neutralizing antibody titers to the recombinant AAV serotype used. The information generated in these trials will be critical to further develop local gene therapy for rheumatoid arthritis patients.

\section{Hurdles and possible solutions for developing AAV gene therapy for clinical application}

As already briefly discussed above, one major problem is the development of immune responses against the vector or against the transgene, resulting in low and/or shortterm transgene expression. The type of immune response depends on a variety of factors, such as the route of application, the target tissue, the vector serotype and dose, the disease targeted, and the expression level of the transgene.

Several strategies have been explored to minimize immune responses against the vector. Since the immune responses are dose dependent, one approach is to optimize the expression cassettes, resulting in higher expression levels using lower doses of vector. Currently, the most widely used promising techniques, at least at the preclinical level, are the use of self-complementary vectors [9] and/or codon-optimized sequences for the expression of transgenes [28]. Such modified gene constructs are being tested in ongoing clinical trials, which should show if these changes translate into clinical benefits.

In many preclinical studies and clinical trials, neutralizing antibodies to AAV were generated after the first injection. Although, ideally, gene therapy should produce lifelong treatment after a single injection, it appears more likely that repeated injections will be needed. One strategy to avoid the negative effect of neutralizing antibodies to the vector after the second injection would be to switch to a different vector serotype. Alternatively, the development of an immune response to the vector might be inhibited by immunosuppressive drugs. Finally, AAV capsid mutants could be designed to escape the induction of immune responses by avoiding uptake of the vector by antigen presenting cells. This last approach may also be advantageous in patients who have pre-existing neutralizing antibodies to AAV due to previous AAV infection [29].

Immune responses to the transgene product mostly occur in diseases where gene therapy is used to replace a "missing" gene and when the transgene is relatively large. Several investigators have demonstrated induction of 
immune tolerance to a therapeutic gene product following gene transfer to hepatocytes [30]. Future studies will be needed to explore the induction of tolerance more precisely in different diseases in which an immune response to the transgene is a problem.

Besides the development of immune responses, there are many other hurdles that need to be overcome. Many of these are disease-, transgene-, or target tissue-specific problems and all need specific solutions to be resolved. For example, the sizes of some therapeutic genes exceed the packaging limit ( $\sim 5 \mathrm{~kb})$ of an AAV vector. Consequently, the design of truncated versions of the transgene, or the development of two vectors expressing fragments of the transgene, is under investigation.

Another challenge may be limited transduction of the target tissue. In addition to escaping the immune response, AAV capsid mutants can improve the transduction efficacy and specific targeting of tissues and cells that are difficult to transduce [31] such as is the case in cystic fibrosis.

One problem that is unlikely to occur with AAV is the safety issues that arise when vectors integrate into the host genome. However, integration is a safety issue with the use of some vectors, such as retroviruses. For example, in a trial for X-linked severe combined immunodeficiency, insertional mutagenesis in the host genome at an oncogenic site led to the development of leukemia in 5 out of more than 20 treated patients [32]. In contrast, no malignancy caused by vectors used in clinical gene therapy trials have been reported in trials predominantly using nonintegrating vectors, such as recombinant AAV (AAV achieves long-term expression by the formation of stable concatemers, but does not generally integrate into the host genome). However, recombinant AAV vectors have shown a very low frequency of integration in the host genome in preclinical studies in mice, but the risk of insertional mutagenesis seems very low [33]. However, future Phase II and III trials have to elucidate if, and how frequently, insertion will occur when large groups of patients are treated with recombinant AAV vectors.

Furthermore, problems concerning the manufacturing of clinical-grade recombinant AAV batches need to be solved. Currently, sufficient GMP-certified labs, which are required to produce the vectors for the European market, are lacking. Standardized methods for batch release, including determining the titer of the batches, are warranted in order to be able to compare the results obtained in studies performed by different labs. It remains to be seen whether it will be possible to overcome the hurdles discussed above.

\section{The next phase in AAV gene therapy trials}

Bringing AAV gene therapy to the clinic is expected to be a relatively long process. However, in the past few years the results generated in Phase I/II clinical trials represent a big step forward for AAV-based gene therapy as treatment for nonlethal diseases. Although clinical trials such as the hemophilia B trial have shown that not all results can be predicted when based on (large) animal models, the Leber's congenital amaurosis trials have shown the safety and (at least partial) efficacy over a longer period after a single injection of an AAV vector. The submission of the first AAV gene therapy product to the EMA is a fact.

Also, AAV gene therapy has shown a good safety profile over a long period of time (follow-up of more than 7 years in patients). Future studies will need to show whether results of AAV gene therapy currently in latephase clinical development are convincing enough to allow these products onto the market.

New advances in the development of AAV gene therapy towards the clinic include the use of alternative serotypes such as recombinant AAV5 for rheumatoid arthritis and recombinant AAV8 for the treatment of hemophilia, or AAV capsid mutants. Different kinetics of uncoating as well as differences in intracellular trafficking and antigen processing may lead to differences in capsid processing and presentation of alternate serotypes. In combination with next generation vectors carrying self-complementary and codon-optimized transgenes, which enhance transgene expression at lower doses, this could perhaps also overcome the problem of pre-existing and newly formed neutralizing antibodies to AAV as well as T-cellmediated immune responses. Furthermore, more data are needed to show if the use of immunosuppressive agents may be sufficiently effective to avoid cellmediated immune-responses.

Overall, gene therapy has enormous potential for treating disease and ways will be found around many of the technical obstacles. It remains to be seen whether we can overcome all of them and fulfill the promise of this approach.

\section{Abbreviations}

AAV, adeno-associated virus; ART-I02, clinical recombinant AAV5 vector expressing human IFN $\beta$; EMA, European Medicines Agency; IFN $\beta$, interferon-beta; IL-1RA, interleukin-1 receptor antagonist; GMP, Good Manufacturing Practice; LPL, lipoprotein lipase; RA, rheumatoid arthritis; RPE65, retinal pigment epithelium-specific $65 \mathrm{kDa}$ protein; scAAV, self-complementary $\mathrm{AAV}$; TNF, tumor necrosis factor; TNFR, TNF receptor; vg, vector genomes. 


\section{Competing interests}

All authors are affiliated with Arthrogen BV, a company developing adeno-associated virus based gene therapy for rheumatoid arthritis.

\section{References}

I. Adriaansen J, Vervoordeldonk MJ, Tak PP: Gene therapy as therapeutic approach for the treatment of rheumatoid arthritis: innovative vectors and therapeutic genes. Rheumatology (Oxford) 2006, 45:656-68.

2. Gene Therapy Clinical Trials Worldwide-The Journal of Gene Medicine Clinical Trial site. [www.abedia.com/wiley/index. html]

3. Maguire AM, High KA, Auricchio A, Wright JF, Pierce EA, Testa F, Mingozzi F, Bennicelli JL, Ying GS, Rossi S, Fulton A, Marshall KA, Banfi S, Chung DC, Morgan JI, Hauck B, Zelenaia O, Zhu X, Raffini L, Coppieters F, De Baere E, Shindler KS, Volpe NJ, Surace EM, Acerra C, Lyubarsky A, Redmond TM, Stone E, Sun J, McDonnell JW, et al.: Age-dependent effects of RPE65 gene therapy for Leber's congenital amaurosis: a phase I dose-escalation trial. Lancet 2009, 374:1597-605.

FI000 Factor 8

Evaluated by Margriet Vervoordeldonk 19 Aug 2011

4. Bainbridge JW, Smith AJ, Barker SS, Robbie S, Henderson R, Balaggan K, Viswanathan A, Holder GE, Stockman A, Tyler N, Petersen-Jones S, Bhattacharya SS, Thrasher AJ, Fitzke FW, Carter BJ, Rubin GS, Moore AT, Ali RR: Effect of gene therapy on visual function in Leber's congenital amaurosis. N Engl J Med 2008, 358:2231-9.

FI000 Factor 8

Evaluated by Margriet Vervoordeldonk 19 Aug 2011

5. Simonelli F, Maguire AM, Testa F, Pierce EA, Mingozzi F, Bennicelli JL, Rossi S, Marshall K, Banfi S, Surace EM, Sun J, Redmond TM, Zhu X, Shindler KS, Ying GS, Ziviello C, Acerra C, Wright JF, McDonnell JW, High KA, Bennett J, Auricchio A: Gene therapy for Leber's congenital amaurosis is safe and effective through 1.5 years after vector administration. Mol Ther 2010, I 8:643-50.

FI000 Factor 6

Evaluated by Margriet Vervoordeldonk 19 Aug 2011

6. Stieger K, Lorenz B: Gene therapy for vision loss - recent developments. Discov Med 2010, 10:425-33.

FI000 Factor 6

Evaluated by Margriet Vervoordeldonk 19 Aug 2011

7. Manno CS, Chew AJ, Hutchison S, Larson PJ, Herzog RW, Arruda VR, Tai SJ, Ragni MV, Thompson A, Ozelo M, Couto LB, Leonard DG, Johnson FA, McClelland A, Scallan C, Skarsgard E, Flake AW, Kay MA, High KA, Glader B: AAV-mediated factor IX gene transfer to skeletal muscle in patients with severe hemophilia B. Blood 2003, I0 I:2963-72.

\section{FI000 Factor 6}

Evaluated by Margriet Vervoordeldonk 19 Aug 2011

8. Manno CS, Pierce GF, Arruda VR, Glader B, Ragni M, Rasko J, Ozelo MC, Hoots K, Blatt P, Konkle B, Dake M, Kaye R, Razavi M, Zajko A, Zehnder J, Rustagi PK, Nakai H, Chew A, Leonard D, Wright JF, Lessard RR, Sommer JM, Tigges M, Sabatino D, Luk A, Jiang H, Mingozzi F, Couto L, Ertl HC, High KA, et al.: Successful transduction of liver in hemophilia by AAV-Factor IX and limitations imposed by the host immune response. Nat Med 2006, I 2:342-7.

FI000 Factor

Evaluated by Margriet Vervoordeldonk 19 Aug 2011

9. Mingozzi F, Maus MV, Hui DJ, Sabatino DE, Murphy SL, Rasko JE, Ragni MV, Manno CS, Sommer J, Jiang H, Pierce GF, Ertl HC, High KA:
CD8(+) T-cell responses to adeno-associated virus capsid in humans. Nat Med 2007, I 3:419-22.

FI000 Factor 8

Evaluated by Margriet Vervoordeldonk 19 Aug 2011

10. Nathwani AC, Rosales C, Mclntosh J, Rastegarlari G, Nathwani D, Raj D, Nawathe S, Waddington SN, Bronson R, Jackson S, Donahue RE, High KA, Mingozzi F, Ng CY, Zhou J, Spence Y, McCarville MB, Valentine M, Allay J, Coleman J, Sleep S, Gray JT, Nienhuis AW, Davidoff AM: Long-term Safety and Efficacy Following Systemic Administration of a Self-complementary AAV Vector Encoding Human FIX Pseudotyped With Serotype 5 and 8 Capsid Proteins. Mol Ther 20I I, 19:876-85.

FI000 Factor 6

Evaluated by Margriet Vervoordeldonk 19 Aug 2011

II. Allay JA, Sleep S, Long S, Tillman DM, Clark R, Carney G, Fagone P, Mclntosh JH, Nienhuis AW, Davidoff AM, Nathwani AC, Gray JT: Good manufacturing practice production of self-complementary serotype 8 adeno-associated viral vector for a hemophilia B clinical trial. Hum Gene Ther 201 I, 22:595-604.

12. Stroes ES, Nierman MC, Meulenberg JJ, Franssen R, Twisk J, Henny $C P$, Maas MM, Zwinderman AH, Ross C, Aronica $E$, High KA, Levi MM, Hayden MR, Kastelein JJ, Kuivenhoven JA: Intramuscular administration of AAVI-lipoprotein lipase S447X lowers triglycerides in lipoprotein lipase-deficient patients. Arterioscler Thromb Vasc Biol 2008, 28:2303-4.

FI000 Factor 6

Evaluated by Margriet Vervoordeldonk 19 Aug 2011

13. Mingozzi F, Meulenberg JJ, Hui DJ, Basner-Tschakarjan E, Hasbrouck NC, Edmonson SA, Hutnick NA, Betts MR, Kastelein J], Stroes ES, High KA: AAV-I-mediated gene transfer to skeletal muscle in humans results in dose-dependent activation of capsid-specific T cells. Blood 2009, I | 4:2077-86.

FI000 Factor 6

Evaluated by Margriet Vervoordeldonk 19 Aug 201 I

14. Gaudet D, de Wal J, Tremblay K, Déry S, van Deventer S, Freidig A, Brisson D, Méthot J: Review of the clinical development of alipogene tiparvovec gene therapy for lipoprotein lipase deficiency. Atheroscler Suppl 2010, I I:55-60.

FI000 Factor 6

Evaluated by Margriet Vervoordeldonk 19 Aug 2011

15. Chan JMK, Villareal G, Jin WW, Stepan T, Burstein H, Wahl SM: Intraarticular gene transfer of TNFR:Fc suppresses experimental arthritis with reduced systemic distribution of the gene product. Mol Ther 2002, 6:727-36.

16. Adriaansen J, Tas SW, Klarenbeek PL, Bakker AC, Apparailly F, Firestein GS, Jorgensen C, Vervoordeldonk MJ, Tak PP: Enhanced gene transfer to arthritic joints using adeno-associated virus type 5: implications for intra-articular gene therapy. Ann Rheum Dis 2005, 64:1677-84.

17. Apparailly F, Khoury M, Vervoordeldonk MJ, Adriaansen J, Gicquel E, Perez N, Riviere C, Louis-Plence P, Noel D, Danos O, Douar AM, Tak PP, Jorgensen C: Adeno-associated virus pseudotype 5 vector improves gene transfer in arthritic joints. Hum Gene Ther 2005, 1 6:426-34.

18. Goodrich LR, Choi WW, Carbone BA, Mcllwraith CW, Samulski RJ: Ex vivo serotype-specific transduction of equine joint tissue by self-complementary adeno-associated viral vectors. Hum Gene Ther 2009, 20:1697-702.

FI000 Factor 6

Evaluated by Margriet Vervoordeldonk 19 Aug 201 I

19. Boutin S, Monteilhet V, Veron P, Leborgne C, Benveniste O, Montus MF, Masurier C: Prevalence of serum IgG and neutralizing factors against adeno-associated virus (AAV) types $I, 2,5,6,8$, and 9 in 
the healthy population: implications for gene therapy using AAV vectors. Hum Gene Ther 2010, 21 :704-12.

FI000 Factor 8

Evaluated by Margriet Vervoordeldonk 19 Aug 2011

20. Jiang H, Couto LB, Patarroyo-White S, Liu T, Nagy D, Vargas JA, Zhou S, Scallan CD, Sommer J, Vijay S, Mingozzi F, High KA, Pierce GF: Effects of transient immunosuppression on AAVmediated, liver-directed gene transfer in rhesus macaques and implications for human gene therapy. Blood 2006, 108:3321-8.

FI000 Factor 6

Evaluated by Margriet Vervoordeldonk 19 Aug 2011

21. Adriaansen J, Khoury M, de Cortie CJ, Fallaux FJ, Bigey P, Apparailly F, Jorgensen C, Vervoordeldonk MJ, Tak PP: Reduction of arthritis following intra-articular administration of an adeno-associated virus serotype $\mathbf{5}$ expressing a disease-inducible TNF-blocking agent. Ann Rheum Dis 2007, 66: I |43-50.

22. Khoury M, Adriaansen J, Vervoordeldonk MJ, Gould D, Chernajovsky Y, Bigey P, Bloquel C, Sherman D, Tak PP, Jorgenson C, Apparailly F: Inflammation-inducible anti-TNF gene expression mediated by intra-articular injection of serotype 5 AAV reduces arthritis. J Gene Med 2007, 9:596-604.

23. Adriaansen J, Fallaux FJ, de Cortie CJ, Vervoordeldonk MJ, Tak PP: Local delivery of beta interferon using an adeno-associated virus type 5 effectively inhibits adjuvant arthritis in rats. J Gen Virol 2007, 88:|7|7-2|

24. Evans $\mathrm{CH}$, Robbins PD, Ghivizzani SC, Wasko MC, Tomaino MM, Kang R, Muzzonigro TA, Vogt M, Elder EM, Whiteside TL, Watkins SC, Herndon JH: Gene transfer to human joints: progress toward a gene therapy of arthritis. Proc Natl Acad Sci U S A 2005, 102:8698-703.

FI000 Factor 6

Evaluated by Margriet Vervoordeldonk 19 Aug 2011

25. Mease PJ, Hobbs K, Chalmers A, El-Gabalawy H, Bookman A, Keystone E, Furst DE, Anklesaria P, Heald AE: Local delivery of a recombinant adenoassociated vector containing a tumour necrosis factor alpha antagonist gene in inflammatory arthritis: a phase I dose-escalation safety and tolerability study. Ann Rheum Dis 2009, 68: I247-54.

FI000 Factor 9

Evaluated by Ulf Mueller-Ladner 05 Aug 2009, Margriet Vervoordeldonk 19 Aug 2011

26. Mease PJ, Wei N, Fudman EJ, Kivitz AJ, Schechtman J, Trapp RG, Hobbs KF, Greenwald M, Hou A, Bookbinder SA, Graham GE, Wiesenhutter CW, Willis L, Ruderman EM, Forstot JZ, Maricic MJ, Dao KH, Pritchard CH, Fiske DN, Burch FX, Prupas HM, Anklesaria P, Heald AE: Safety, tolerability, and clinical outcomes after intraarticular injection of a recombinant adeno-associated vector containing a tumor necrosis factor antagonist gene: results of a phase I/2 Study. J Rheumatol 2010, 37:692-703.

FI000 Factor 6

Evaluated by Margriet Vervoordeldonk 19 Aug 201I

27. Frank KM, Hogarth DK, Miller JL, Mandal S, Mease PJ, Samulski RJ, Weisgerber GA, Hart ]: Investigation of the cause of death in a gene-therapy trial. $N$ Engl J Med 2009, 36 I:I6I-9.

FI000 Factor

Evaluated by Margriet Vervoordeldonk 19 Aug 201 I

28. DiPrimio N, McPhee SW, Samulski RJ: Adeno-associated virus for the treatment of muscle diseases: toward clinical trials. Curr Opin Mol Ther 2010, I 2:553-60.

FI000 Factor 8

Evaluated by Margriet Vervoordeldonk 19 Aug 2011

29. Märsch S, Huber A, Büning $H$, Hallek M, Perabo L: Optimization of stealth adeno-associated virus vectors by randomization of immunogenic epitopes. Virology 2010, 397:167-75.

FI000 Factor 6

Evaluated by Margriet Vervoordeldonk 19 Aug 201 I

30. LoDuca PA, Hoffman BE, Herzog RW: Hepatic gene transfer as a means of tolerance induction to transgene products. Curr Gene Ther 2009, 9:104-14.

FI000 Factor 8

Evaluated by Margriet Vervoordeldonk 19 Aug 201 I

3I. Märsch S, Huber A, Hallek M, Büning H, Perabo L: A novel directed evolution method to enhance cell-type specificity of adenoassociated virus vectors. Comb Chem High Throughput Screen 2010, 13:807-12.

FI000 Factor 6

Evaluated by Margriet Vervoordeldonk 19 Aug 201 I

32. Deichmann A, Hacein-Bey-Abina S, Schmidt M, Garrigue A Brugman MH, Hu J, Glimm H, Gyapay G, Prum B, Fraser CC, Fischer N, Schwarzwaelder K, Siegler ML, de Ridder D, PikeOverzet K, Howe SJ, Thrasher AJ, Wagemaker G, Abel U, Staal FJ, Delabesse E, Villeval JL, Aronow B, Hue C, Prinz C, Wissler M, Klanke C, Weissenbach J, Alexander I, Fischer A, et al.: Vector integration is nonrandom and clustered and influences the fate of Iymphopoiesis in SCID-XI gene therapy. J Clin Invest 2007, I I 7:2225-32.

FI000 Factor 6

Evaluated by Margriet Vervoordeldonk 19 Aug 2011

33. Li H, Malani N, Hamilton SR, Schlachterman A, Bussadori G, Edmonson SE, Shah R, Arruda VR, Mingozzi F, Wright JF, Bushman FD, High KA: Assessing the potential for AAV vector genotoxicity in a murine model. Blood 20II, I I 7:33 II-9.

FI000 Factor 6

Evaluated by Margriet Vervoordeldonk 19 Aug 201 I 